\title{
Synthesis of some Aryl sulfonamide Compounds from o-Nitrotoluene
}

\author{
Mohammed A. Sheat Asmaa H. Sultan Amera M. Farage \\ Department of Chemistry \\ College of Science \\ Mosul University
}

(Received 18/10/2010; Accepted 14/3/2011)

\begin{abstract}
2-Nitro-4-Methyl benzene sulphonyl chloride (I) has been prepared through sulphonation reaction from chlorosulphonic acid and o-nitrotoluene. Then compound (I) was allowed to react with primary and secondary amines to give a number of sulfonamide compounds $\left(\mathrm{II}_{1-14}\right)$. data.

The synthesized compounds were identified depending on the physical and spectral
\end{abstract} Keyword: sulfonamide compounds.

\section{تحضير بهض مركبلت الارلمسافوناميدمن الورثو -ناليتروتولون}

\section{Iلالهص}

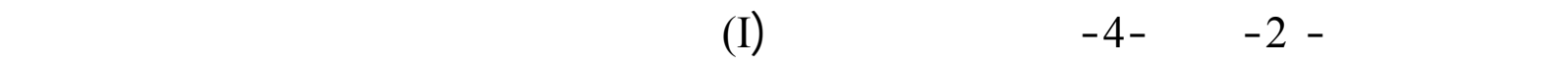

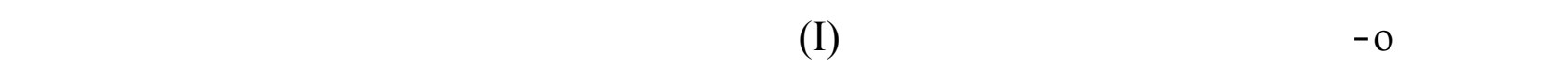
للسفوناميد (II-14). شخصت الصبغ التركيبية للمركبلت المحضرة بالاعتماد على البيانت الفيزياوية والطيفية. الكلمات الفغتلحية : مركبلت السلفونميد .

\section{INTRODUCTION}

Arylsulfonamide compounds were known to possess various biological activities, sulfonamides are synthetic antimicrobial agents which act as competitive inhibitors of the enzyme dihydropteroate synthetase (DHPS) (wikipedia, 2009).

Hypoglycemic sulfonamides used in the treatment of type 2 diabetes mellitus ( loub, 2007). Some sulfonamide detective like u,z- Bisarylsufonyl Hydrazine used in antineoplastic , anti- inflammatory, antitubercular (Mohammed et al., 2006).

Benzothiazolyl benzene sulfonamide used in cerebro and cardiovascular Dilating agents (Ahmed, 2006), therefore many investigators reported the synthesis of this type of compounds due to the importance of this compound in the medical, industrial and other fields. The norbornem sulfonamide used to prepared Romp Polymer which have more stable 
polymers (Kasyan, 2001). Also some sulfonamide derivatives used herbicides (Guuny et al., 1999), the common method for the synthesis is by hinsbery reaction which include react primary or secondary amines with sulfonylchloride in the presence of pyridine (R.T Marrson et al., 1973).

\section{EXPERIMENTAL}

Melting points were determined using electrothermal 9300 Engineering Ltd apparatus and are uncorrected. IR. spectra were recorded by FT-IR spectrophotometer model Tensor 27-Bruker Co. German 2003 as (KBr) disc. UV. spectra were obtained by Shimadzu UVVIS recording UV-1650 PC spectrophotometer using absolute ethanol as solvent.

\section{Preparation of 2-Nitro-4- Methyl benzene sulphonyl chloride (I) (N. C. Rose, 1970):}

To O- nitrotoluene (sul, 0.073 mole), chlorosulfonic acid $(10 \mathrm{~m},, 0.15$ mole) was added. The mixture was reflected fo 30 mintues. Then cooled in an ice bath, poured into 100 $\mathrm{g}$ of crushed ice, then extracted with $(2 \times 20 \mathrm{ml})$ diethylether. The ether layer was stirred vigorously with $25 \mathrm{ml}$ ammonium hydroxide. The stirring was continued to complete the precipitation, the solid material was separated by filteration, washed with cold water, air dried, recrysttallized from water to give yield 707. of the titled product with mp (25-30 C) (Rose, 1970).

The spectral data of compound (I) showed the following characteristic absorption bands:
$v \mathrm{~N}=\mathrm{O} 1522 \mathrm{~cm}^{-1}(\mathrm{~s})$
$v \mathrm{~N}=\mathrm{O} 1330 \mathrm{~cm}^{-1}(\mathrm{~s})$
assymetric stretching of No2 Group
$v \mathrm{~S}=\mathrm{O} 1298 \mathrm{~cm}^{-1}(\mathrm{~m})$ symmetric stretching of No2 Group
v $\mathrm{S}=\mathrm{O} 1164 \mathrm{~cm}^{-1}(\mathrm{~s})$
v $C=-C 1613 \& 1478 \mathrm{~cm}^{-1}$ assymetric stretching of So2 Group symetric stretching of So2 Group

The UV spectrum show bonds at X max (abs. Etoh) $278 \mathrm{~nm}$.

\section{Preparation of sulfonamide compounds (II 1-14) ( Frank, 1947):}

Compound (I) (0.01 mole) was dissolved in absolute ethanol $(15 \mathrm{ml})$, then dry pyridine (5-7 drops) was added to the mixture. The mixture was stirred at room temperature for (15 minutes). Amino compound (0.01 mole) was added gradually with stirring. The stirring was continued for ( $24 \mathrm{hrs})$ at room temperature. After the addition of the mixture into a beaker containing crushed ice, precipitate was formed. The precipitate was filtered, washed with cold water and recrystallized from ethanol to yield the synthesized compounds $\left(\mathrm{I}_{1-14}\right)$. The physical and spectral data were illustrated in Table(1).

\section{RESULT AND DISCUSSION}

The previous studies showed that some sulfonamides had pharmaceutical activity. The sulfonamido group take part in giving different biological activities (Wilson et al.,1982) (Hanafy et al., 2007). Moreover, the hetrocyclic substituted sulfonamides were found to be the best drugs among sulfa drugs (Moore et al., 1978). Therefore, we described here the possibility of synthesing of sulfonamides containing heterocyclic groups in order to obtain expected biologically active sulfonamides Scheme 1 . 


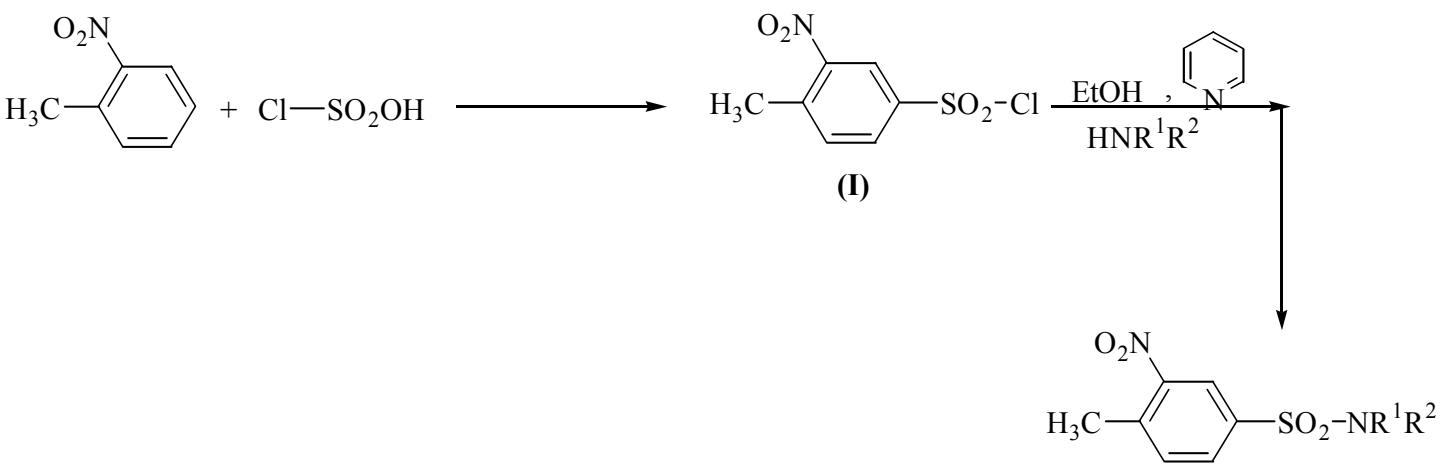

(I 1-14)

Scheme 1

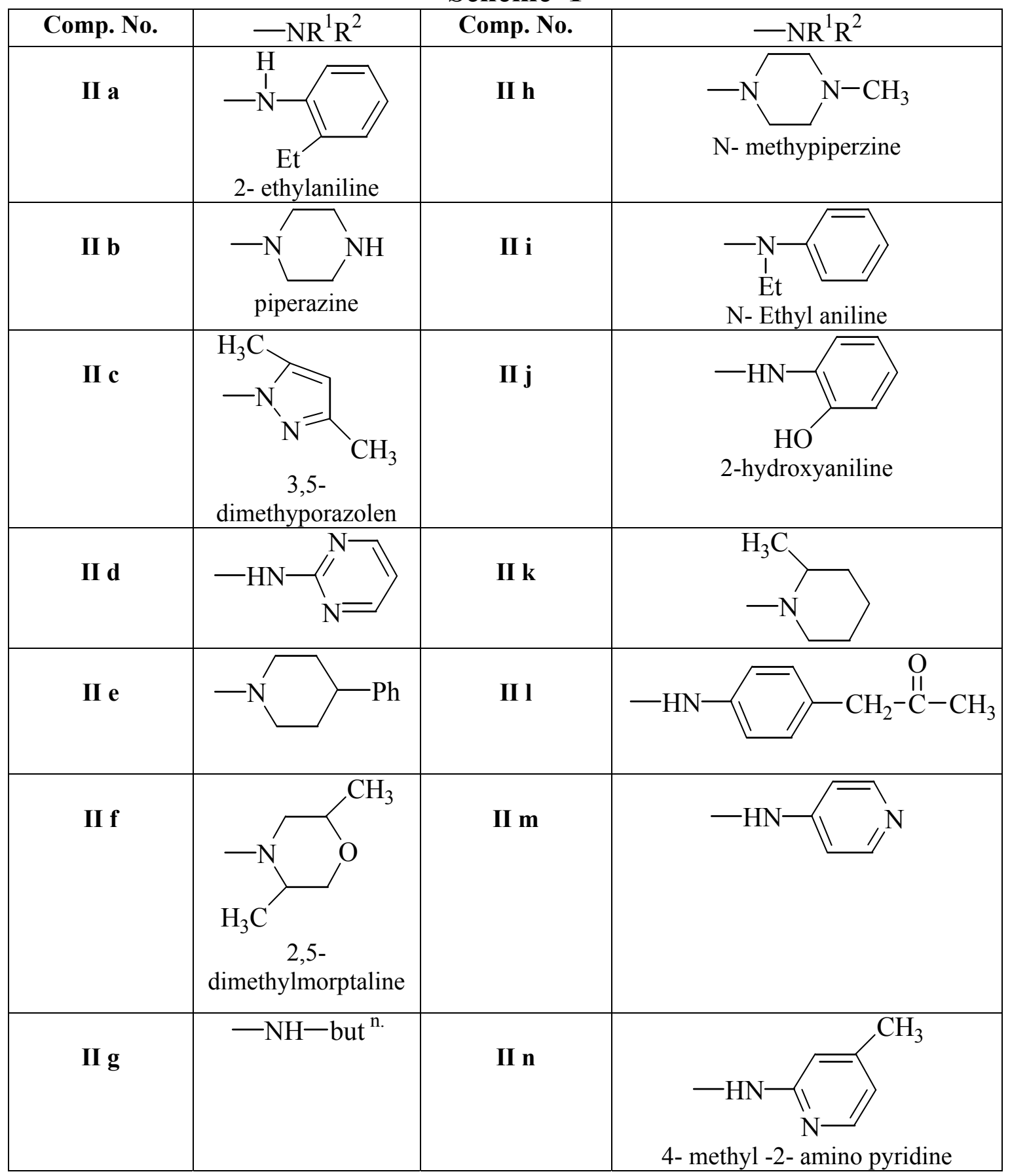


Table 1 : physical and spectral data of sulphanomide compounds (II 1-14).

\begin{tabular}{|c|c|c|c|c|c|c|c|}
\hline \multirow{2}{*}{$\begin{array}{c}\text { Comp. } \\
\text { No. }\end{array}$} & \multirow{2}{*}{$\begin{array}{c}\text { Yield } \\
\%\end{array}$} & \multirow{2}{*}{$\underset{{ }^{\circ} \mathbf{C}}{\mathbf{m . p}}$} & \multicolumn{4}{|c|}{ IR. $(\mathrm{KBr}) \mathrm{cm}^{-1}$} & \multirow{2}{*}{$\begin{array}{l}\text { UV. } \\
\text { EtOH } \\
\lambda \max \\
(\mathrm{nm})\end{array}$} \\
\hline & & & v $\mathrm{N}=\mathrm{O}$ & v $S=0$ & v N-H & others & \\
\hline II $\mathbf{a}$ & 85 & $114-115$ & $\begin{array}{l}1516 \\
1320\end{array}$ & $\begin{array}{l}1325 \\
1139\end{array}$ & 3419 & ---- & 268 \\
\hline II b & 55 & $230-233$ & $\begin{array}{l}1512 \\
1314\end{array}$ & $\begin{array}{l}1362 \\
1155\end{array}$ & 3385 & $\begin{array}{l}\text {---- } \\
----\end{array}$ & 260 \\
\hline II c & 45 & $149-150$ & $\begin{array}{l}1530 \\
1348\end{array}$ & $\begin{array}{l}1348 \\
1148\end{array}$ & & $\begin{array}{l}\mathrm{C}=\mathrm{N} \\
1617\end{array}$ & 256 \\
\hline II d & 65 & $208-210$ & $\begin{array}{l}1488 \\
1316\end{array}$ & $\begin{array}{l}1331 \\
1157\end{array}$ & 3396 & $\begin{array}{l}\mathrm{C}=\mathrm{N} \\
1624\end{array}$ & 252 \\
\hline II e & 70 & $169-170$ & $\begin{array}{l}1555 \\
1300 \\
\end{array}$ & $\begin{array}{l}1345 \\
1165 \\
\end{array}$ & & & 246 \\
\hline II f & 82 & $110-112$ & $\begin{array}{l}1546 \\
1326 \\
\end{array}$ & $\begin{array}{l}1337 \\
1167 \\
\end{array}$ & & & 250 \\
\hline II $\mathrm{g}$ & 87 & $66-67$ & $\begin{array}{l}1527 \\
1338 \\
\end{array}$ & $\begin{array}{l}1338 \\
1174\end{array}$ & 3455 & & 240 \\
\hline II h & 50 & $120-122$ & $\begin{array}{l}1527 \\
1343\end{array}$ & $\begin{array}{l}1343 \\
1176\end{array}$ & & & 250 \\
\hline II i & 80 & $127-128$ & $\begin{array}{l}1529 \\
1350\end{array}$ & $\begin{array}{l}1350 \\
1147\end{array}$ & & & 244 \\
\hline II j & 88 & $134-136$ & $\begin{array}{l}1514 \\
1331 \\
\end{array}$ & $\begin{array}{l}1340 \\
1142 \\
\end{array}$ & v N-H & $\begin{array}{l}+v \mathrm{O}-\mathrm{H} \\
430\end{array}$ & 254 \\
\hline II k & 86 & $80-81$ & $\begin{array}{l}1528 \\
1345 \\
\end{array}$ & $\begin{array}{l}1345 \\
1137\end{array}$ & & & 242 \\
\hline II I & 76 & $130-131$ & $\begin{array}{l}1496 \\
1334 \\
\end{array}$ & $\begin{array}{l}1334 \\
1154 \\
\end{array}$ & 3355 & $\begin{array}{c}v \mathrm{C}=\mathrm{O} \\
1680\end{array}$ & 260 \\
\hline II m & 50 & $267-270$ & $\begin{array}{l}1491 \\
1318 \\
\end{array}$ & $\begin{array}{l}1338 \\
1150\end{array}$ & 3391 & & 250 \\
\hline II n & 76 & $257-260$ & $\begin{array}{l}1523 \\
1324\end{array}$ & $\begin{array}{l}1360 \\
1164\end{array}$ & 3389 & & 244 \\
\hline
\end{tabular}

The reaction mechanism of benzene sulfonyl chloride with primary and secondary amines was occurred through neuclophilic substitution reaction similar to that of (SN2):

The structural formula of the synthesized sulfonamide compounds (II 1-14) have been investigated according to their physical and spectral data (IR and UV) (Parikh, 1974).

The IR spectra of the synthesized compounds (II 1-14) showed the appearance of two strong absorption bands at the regions (1546-1488) $\mathrm{cm}^{-1}(1350-1300) \mathrm{cm}^{-1}$ due to the asymmetric and symmetric stretching vibrations of $\left(\mathrm{NO}_{2}\right)$ group respectively, also two absorption bands appeared at the regions (1362-1325) $\mathrm{cm}^{-1}$ and $(1176-1137) \mathrm{cm}^{-1}$ due to 
asymmetric and symmetric stretching vibration of $\left(\mathrm{SO}_{2}\right)$ group respectively. The broad band at (3455-3283) $\mathrm{cm}^{-1}$ is due to stretching vibration of $(\mathrm{N}-\mathrm{H})$ bond.

Sometimes, the symmetric stretching vibration band of $\left(\mathrm{NO}_{2}\right)$ group was overlapped with the asymmetric stretching vibration of $\left(\mathrm{SO}_{2}\right)$ group which appeared as single band at the same region.

The UV. Spectra of synthesized sulfonamide compounds (II 1-14) showed lower $\lambda$ max. values as compared with compound (I). This is due to the sulfonamido group, which affect the $n \rightarrow \pi^{*}$ transition leading to decrease the $\lambda$ ma $X$ values to all the synthesized compounds.

\section{المصادر الأجنبية}

Al-Hyalee, A. (2006). Synthesis of Schiff bases of some p - amino phenol derivatives, M.Sc THESIS, University of Mosul, Mosul, Iraq, 22p.

Atieres, L.; Mariani, M. (2007). The discovery of hypoglycemic sulfonamides, J. Soc. Bio. 201 (2), $121-125$.

Frank, H. B. ; Losee, K. ; Lott, W.A. (1947). Amino sulfoni lanisides. J. Am. Chem. Soc., 69(4), 583.

Hanafy, A.; Uno, J.; Mitani , H. (2007). Effect of novel N- arylsulfanomide substituted 3morpolino are coline derivative. J. Bioorganic and Medical Chem., 16 (9), 51-57.

Kasyan, (1995). Flurine - containing norbornene series sulfonamide. ZH. Org. khim, 31(3), 357-364.

Marrson, R.T.; Boydl, R.N. (1973). "Organic Chemistry". Allyn and Bacon, Inc 3rd edn., pp. 750-798.

Moore, J. A. ; Barton, T. J. (1978). " Organic Chemistry ". W.B. Saunders Company, 314p.

Parikh, V. M. (1974). "Absorption Spectroscopy of Organic Molecules". Wesley Publishing Company, London .

Rose, N.C. ; Rome, S. (1970). Preparation of 6- Amino Saccharin. J. Chem, Edu. , 47 (9), $649-650$.

Sheat, M.; Saeed, Z.(2006). Synthesis and study of Acetylenic Amines derivatvatives contaning sulfanomido, B- Nophothoxy and Hippurate groups. Nat. J. Chem. 21, 53-62.

Sulfanomide - (Medicine) . (2009). wikipedia, "The Free Encyclopedia" http://en.wikipedia.org/wiki/su/fonamide(medicine).

Wilson, A. ; Gisvold's, H. (1982). " Text Book of Organic Medicinal and Pharmaceutal Chemistry ", J. B. Lippincott company, New York, 189p.

Yung, F.G. ; Liu, H.Y. (1999). Q sar and 3 D -Q sar analysis of structurally diverse ALS inhibitors: sulfony / ureas and triazolo pyrmidine - 2- sulfanomide, J. anyl. Chem.. 55 (12), 1147 - 1150. 